\title{
PENINGKATAN KETERAMPILAN BERBICARA MELALUI TEKNIK BERCERITA MAHASISWA TINGKAT 1 PROGRAM STUDI KEPERAWATAN STIKES SYEDZA SAINTIKA PADANG
}

\author{
Ayu Gustia Ningsih ${ }^{1}$ \\ Sekolah Tinggi Ilmu Kesehatan Seyedza Saintika Padang, Sumatera Barat \\ ayugustianingsih@gmail.com
}

\begin{abstract}
Indonesian language learning is still applied with teacher centered learning in which the students face difficulty in asking questions. The students tend to be lazy to do their homework if they do not understand their materials. The lack of motivation and activities cause minimum of their assessment. This research is aimed at identifying the influence of story telling technique in increasing students learning outcome in Indonesian language course in nursery study program STIKes Syedza Saintika Padang. Based on the problem, the story telling technique is expected to increase students activities and their learning outcome. This research is classroom actions research and the subject of the research is 25 people of the first semester students of nursery study program STIKes Syedza Saintika Padang. The data is collected by using observation shheets and result tests. The technique of analyzing the data is descriptive and supported by the analysis of students learning outcome. This research is divided into 2 cycles and each of the cycles consist of 3 meetings. The result shows that cycle I mean is 65,55 and cycle II is 88,96. This shows that there is an increase of students acitivities. Moreover, it can be concluded that Indonesian language can be taught by using story telling technique in order to increase their activities and learning outcomes.
\end{abstract}

Key Words: improving, speaking ability, story telling technique

\footnotetext{
${ }^{1}$ Dosen Sekolah Tinggi Ilmu Kesehatan Seyedza Saintika Padang, Sumatera Barat.
} 


\section{PENDAHULUAN}

Pembelajaran berbicara di STIKes Syedza Saintika Padang belum terlaksana dengan baik. Berdasarkan observasi awal pada mahasiswa tingkat 1 program studi keperawatan STIKes Syedza Saintika Padang ditemukan berbagai masalah yang dapat diidentifikasi. Pertama, adanya anggapan yang tidak baik dari mahasiswa terhadap pembelajaran berbicara. Kedua, pembelajaran berbicara kurang menyenangkan karena kurang melibatkan mahasiswa dalam proses pembelajaran. Ketiga, jumlah mahasiswa yang aktif baik yang bertanya maupun yang menjawab pertanyaan dalam proses belajar mengajar jauh lebih sedikit dari pada jumlah mahasiswa yang tidak aktif. Keempat, ketakutan dan ketidak beranian mahasiswa timbul apabila berbicara di depan kelas. Kelima, proses pembelajaran untuk aspek berbicara tidak menarik.

Bertolak dari identifikasi masalah, yang dibahas dalam penelitian ini adalah berkaitan dengan peningkatan keterampilan berbicara. Dalam penelitian ini, masalah dibatasi pada peningkatan kemampuan berbicara mahasiswa tingkat 1 program studi keperawatan STIKes Syedza Saintika Padang dengan teknik bercerita. Berdasarkan batasan masalah di atas, rumusan masalah dalam penelitian ini adalah apakah penggunaan teknik bercerita dapat meningkatkan keterampilan berbicara mahasiswa tingkat 1 program studi keperawatan STIKes Syedza Saintika Padang? Berdasarkan rumusan masalah di atas maka, penelitian ini bertujuan untuk mendeskripsikan penggunaan teknik bercerita sebagai upaya untuk meningkatan keterampilan berbicara mahasiswa tingkat1 program studi keperawatan STIKes Syedza Saintika Padang .

Albert (et al) dalam Tarigan, HG (1985:26) menyatakan "Kemampuan berbicara merupakan suatu unsur penting terhadap keberhasilan kita dalam semua bidang kehidupan". Dengan kata lain, kemampuan berbicara sangatlah mendukung sukses tidaknya seseorang dalam menjalani hidup dan masa depannya karena manusia hidup secara bersama-sama dalam lingkungan sosial yang membutuhkan komunikasi yang baik.

Mendukung pernyataan di atas, Sameto (2004:1) menyatakan" Berbicara yang efektif merupakan sarana penyampaian ide kepada orang atau khalayak secara lisan dengan cara yang mudah dicerna dan dimengerti oleh pendengarnya". Senada dengan pendapat di atas Maidar (1991:23) menyatakan bahwa "Kemampuan berbicara adalah kemampuan mengucapkan kalimatkalimat untuk mengekspresikan, menyatakan, menyampaikan pikiran, gagasan dan perasaan". Jadi kemampuan berbicara adalah cara untuk mengekspresikan apa yang dipikirkan dan yang dirasakan untuk diberitahukan kepada orang lain.

Menurut Keraf (1996:34) keterampilan berbicara adalah: "Kemampuan memilih dan menata gagasan secara logis dan sistematis menuangkan ke dalam kode kebahasaan sesuai dengan kaidah bahasa yang digunakan sesuai konteks komunikasi yang sesuai dan mengucapkannya dengan lancar dan jelas.

Senada dengan pendapat di atas menurut Tarigan, HG(1985:15) "Berbicara adalah kemampuan mengucapkan bunyi-bunyi artikulasi atau 
kata-kata untuk mengekspresikan, menyatakan, serta menyampaikan pikiran, gagasan, dan perasaan". Sebagai perluasan dari batasan di atas, dapat dikatakan bahwa berbicara merupakan suatu sistem tanda-tanda yang dapat didengar dan kelihatan untuk mengungkapkan dan mengekspresikan pikiran dan gagasan pembicara agar maksud dan tujuan pembicara dapat tercapkan.

Keterampilan berbicara tidak tumbuh dan berkembang dengan sendirinya melainkan didahului dengan keterampilan menyimak. Menurut Tarigan dan H.G. Tarigan ( 1990:86) bahwa: Setiap keterampilan berbahasa saling menunjang. Menyimak dan berbicara adalah dua kegiatan yang tak terpisahkan. Kegiatan menyimak pastilah didahului oleh kegiatan berbicara. Pembicara yang baik pastilah memberikan contoh yang dapat ditiru oleh penyimak yang baik. Pembicara yang baik memudahkan penyimak untuk menangkap pembicaraan yang disampaikan. Keterampilan berbicara menunjang pula keterampilan menulis sebab pada hakikatnya antar berbicara dan menulis terdapat persamaan dan perbedaan.

Sesuai dengan pendapat di atas, Maidar (1991:23) menyatakan "Keterampilan berbicara bukanlah kemampuan yang berdiri sendiri, tetapi saling berkaitan dengan kemampuan yang lain. Kegiatan berbicara berhubungan erat dengan kegiatan mendengarkan. Berbicara dan mendengarkan merupakan kegiatan komunikasi dua arah". Jadi keefektifan berbicara tidak hanya ditentukan oleh $\mathrm{Si}$ pembicara tetapi juga oleh para pendengar.
Kemampuan berbicara adalah suatu kemampuan berbahasa yang kompleks. Dalam proses berbicara, terdapat proses menyimak informasi yang disampaikan oleh pembicara. Sesuai dengan yang diungkapkan oleh Akhadiah (1988:27) "Bahwa kemampuan berbicara adalah salah satu kemampuan berbahasa yang kompleks, yang tidak hanya sekedar mencakup persoalan ucapan/lafal dan intonasi saja". Sejalan dengan pendapat di atas Hendrikus (1991:14) menyatakan "Berbicara berarti mengucapkan kata atau kalimat kepada seseorang atau sekelompok orang untuk mencapai suatu tujuan tertentu". Berarti berbicara adalah suatu penyampaian tujuan tertentu pada seseorang atau sekelompok orang.

Setiap orang yang berbicara pastilah punya tujuan yang ingin dicapai. Menurut Keraf (1996:38) berbicara mempunyai empat tujuan umum antara lain: (a) mendorong, tujuannya agar pendengar mempunyai inspirasi sehingga mau dan mampu melakukan sesuatu kegiatan,pembicaraan harus didasarkan pada kebutuhan, keinginan dan harapan pendengar; (b) meyakinkan, pembicara berusaha untuk mempengaruhi keyakinan atau sikap, mental/intelektual para pendengar untuk tujuan meyakinkan; (c) memberitahukan dan menyampaikan informasi, pembicara ingin memberitahukan/menyampaikan sesuatu kepada pendengar agar mereka dapat mengerti tentang sesuatu hal atau memperluas pengetahuan mereka; dan (d) menyenangkan, pembicra dengan maksud menggembirakan yang mendengarkan pembicarannya, dengan tujuan menyenangkan. Kegiatan berbicara ini bertujuan untuk menarik perhatian pendengar terhadap berbagai informasi yang diberikan yang 
disampaikan secara spontan, humor dan memikat.

Kesempatan untuk tampil berbicara di depan umum sangatlah dibutuhkan keterampilan berbicara yang baik. Osborne (1990:89) menyatakan "Kunci bagi keberhasilan dalam menyampaikan pembicaraan pada kesempatankesempatan khusus adalah dengan memahami tuntutan yang berbeda-beda dari masing-masing kesempatan itu dan mempersiapkan diri dengan baik sebelum tampil.

Selain mempunyai tujuan yang ingin dicapai, pengajaran keterampilan berbicara juga memiliki manfaat yang bisa diberikan pada mahasiswa. Adapun manfaat pengajaran keterampilan berbicara menurut Arief dan Yarni Munaf (2003:206-207) adalah: "Membimbing mahasiswa mampu berdialog dengan orang lain dengan mempertimbangkan siapa yang diajak berbicara sehingga pembicaraan akan berlangsung menyenangkan dan sopan. Mahasiswa juga dibimbing untuk mampu mengemukakan gagasan, pendapat, pengalaman dan perasaannya secara logis dan sistematis dalam berbagai bentuk dan gaya.

Maidar dan Mukti U.S (1991:1722) menjelaskan faktor-faktor penunjang dalam berbicara yaitu: Faktor kebahasaan antara lain: 1) ketepatan ucapan, 2) penempatan tekanan, 3) pilihan kata (diksi). Sedangkan faktor nonkebahasaan, antara lain: 1) sikap yang wajar tenang dan tidak kaku, 2) pandangan harus diarahkan pada lawan bicara, 3) gerak gerik dan mimik yang tepat, 4) kenyaringan suara, 5) kelancaran, 6) relevansi/penalaran, 7) penguasaan topik.

Untuk mencapai tujuan pengajaran diperlukan teknik-teknik tertentu dalam proses belajar mengajar. Hidayat dkk (1987:60) menyatakan "....Jadi teknik tiada lain hanyalah kelanjutan dari metode, sedangkan arahannya harus sesuai dengan approach, kemudian menentukan metode-metode yang cocok dengan tujuan kuliah dan baru memikirkan daya upaya menyampaikan bahan itu kepada para mahasiswa".

Menurut Hidayat dkk (1987:60) "Teknik pengajaran adalah cara-cara dan alat-alat yang digunakan guru dalam kelas. Teknik adalah daya upaya, usahausaha atau cara-cara yang digunakan guru dalam mencapai tujuan langsung dalam pelaksanaan pengajaran dalam waktu itu". Adapun teknik-teknik yang dimaksud menurut Saliwangi (1989:56) adalah" 1) ceramah, 2) Tanya jawab, 3) diskusi kelompok, 4) pemberian tugas, 5) studi kasus, 6) brain Storming, 7) eksperimen, 8) simulasi, 9) sosiodrama dan sebagainya".

Dalam pengajaran keterampilan berbicara juga terdapat teknik-teknik yang bisa digunakan guru untuk menunjang pencapaian tujuan pembelajaran. Dari sekian banyak teknikteknik yang digunakan dalam pengajaran keterampilan berbicara peneliti memilih teknik bercerita karena menurut pemikiran peneliti akan lebih efektif digunakan dan tidak membutuhkan alat dan bahan yang banyak. Dalam KBBI (2002:210) diyatakan "Bercerita adalah menuturkan cerita". Mendukung pendapat diatas, Tarigan dan H.G Tarigan (1990:116) menyatakan "Bercerita atau menceritakan suatu cerita tertentu di depan umum jelas menuntut keterampilan berbicara. Gaya bercerita yang menarik, intonasi yang tepat,

\section{Peningkatan Keterampilan Berbicara Melalui Teknik Bercerita Mahasiswa Tingkat 1 Program Studi Keperawatan Stikes Syedza Saintika Padang}


pengurutan cerita yang cocok dan sebagainya harus dikuasai benar-benar".

Adapun langkah-langkah teknik bercerita menurut Tarigan dan H.G Tarigan (1990:116) adalah sebagai berikut:

1. Mahasiswa disuruh memilih cerita yang disukai baik oleh pencerita maupun oleh pendengarnya

2. Mahasiswa menyimak atau membaca dan menghafalkan cerita tersebut

3. Mahasiswa bercerita tanpa teks semuanya diluar kepala dan diceritakan kepada mahasiswa lain.

Menurut Ratna dan Abdurrahman (2003:112-117) dalam menilai keterampilan berbicara dengan bercerita ada tiga aspek yang akan dinilai yaitu "Bahasa, isi dan penampilan. Setiap aspek tersebut mempunyai beberapa indikator, untuk aspek bahasa indikatornya adalah a) lafal, b) kosakata/diksi, c) struktur/gramatika, d) gaya bahasa, selanjutnya untuk aspek isi indikatornya adalah a) hubungan isi dengan topik, b) organisasi isi, c) kuantitas isi dan d) kualitas isi, terakhir aspek penampilan indikatornya adalah a) gerak gerik dan mimik, b) hubungan dengan pendengar, c) volume suara, d) jalannya cerita".

Berdasarkan indikator penilaian di atas, maka dalam penelitian ini indikator penilaian peneliti batasi dalam enam indikator saja. Hal ini sesuai dengan pendapat Suhendar dan Pien Supinah (1997: 118-131) dalam penilaian keterampilan berbicara jenis cerita ada enam hal yang harus diperhatikan yaitu:

a) Lafal dan ucapan

b) Tata bahasa, struktur kebahasaan yang sesuai dengan ragam bahasa yang dipakai c) Kosakata/diksi pilihan kata yang tepat sesuai dengan makna informasi yang akan disampaikan.

d) Kefasihan, kemudahan dan kecepatan berbicara

e) Isi pembicaraan .

f) Pemahaman

\section{B. METODE}

Jenis penelitian ini adalah penelitian tindakan kelas (PTK). Arikunto (2006:3) menjelaskan bahwa penelitian tindakan kelas (PTK) "Merupakan suatu pencermatan terhadap kegiatan belajar berupa sebuah tindakan yang sengaja dimunculkan dan terjadi dalam sebuah kelas yang terjadi secara bersama". Tindakan tersebut diberikan oleh guru atau dengan arahan guru yang dilakukan oleh mahasiswa. Peneliti berusaha mengkaji secara kritis dan objektif suatu rencana pembelajaran terhadap peningkatan keterampilan berbicara mahasiswa dengan menggunakan metode bercerita dengan menggunakan jenis penelitian tindakan kelas (PTK).

Pada prinsipnya penelitian tindakan kelas terdiri empat unsur yaitu (1) perencanaan, (2) tindakan, pengamatan, (4) refleksi yang merupakan dasar untuk suatu rancangan pemecahan masalah. Empat unsur tersebut harus ada dalam satu siklus, karena setiap unsur mempunyai hubungan dengan unsur lain.

Pola pelaksanaan penelitian tindakan ini menggunakan "model siklus". Hal ini sesuai dengan Arikunto (2006:117) menyatakan bahwa "Model siklus ini terdiri dari empat komponen yaitu perencanaan, tindakan, pengamatan dan refleksi. Apabila satu siklus belum menunjukkan tanda-tanda perubahan atau perbaika (peningkatan mutu), kegiatan penelitian dilanjutkan pada siklus kedua

\section{Peningkatan Keterampilan Berbicara Melalui Teknik Bercerita Mahasiswa Tingkat 1 Program Studi Keperawatan Stikes Syedza Saintika Padang}


dan seterusnya sampai peneliti merasa puas".

Pengumpulan data dalam penelitian ini dilakukan sebanyak dua siklus. Setiap siklus diharapkan adanya perubahan yang diperoleh. Di akhir siklus hasilnya dianalisis baik dalam bentuk keberhasilan maupun kegagalan sebagai bahan pertimbangan untuk siklus sebelumnya.

Proses pengumpulan data dilakukan dengan beberapa tahap: 1) mahasiswa ditugaskan bercerita dengan topik yang telah ditentukan dan direkam dengan alat perekam, 2) peneliti sebagai pengamat menilai tes keterampilan berbicara dengan teknik bercerita menggunakan skala penilaian yang telah ditentukan, 3) menganalisis hasil yang didapat pada siklus pertama.

Data yang telah terkumpul dianalisis melalui tahap berikut ini: pertama, mengecek nama dan kelengkapan identitas mahasiswa, kedua, pemberian skor terhadap keterampilan berbicara dengan teknik bercerita, hasil berbicara mahasiswa yang telah direkam dianalisis sesuai dengan pedoman penilaian yang telah ditentukan.

\section{HASIL DAN PEMBAHASAN}

Pelaksanaan penelitian pada siklus pertama dalam penelitian tindakan kelas dilaksanakan berdasarkan data studi pendahuluan yang telah dilakukan sebelumnya. Siklus I ini dilaksanakan dalam dua kali pertemuan yaitu pada tanggal $4-6$ Oktober 2017, pertemuan pertama dilaksanakan pada hari Rabu pada tanggal 4 Oktober 2017 sedangkan pertemuan kedua dilaksanakan pada hari Kamis tanggal 6 Oktober 2017.

Pada tahap penelitian siklus I, dijelaskan bagaimana cara penerapan teknik bercerita dalam perencanaan, pelaksanaan, pengamatan dan refleksi penelitian tindakan kelas dalam pembelajaran bahasa Indonesia khususnya untuk meningkatkan keterampilan berbicara mahasiswa. Penggunaan teknik bercerita tersebut akan terlihat dalam kegiatan pada pertemuan kedua.

Selama siklus I berlangsung, hal yang diamati mengenai hasil berbicara mahasiswa yang telah dilaksanakan pada akhir siklus. Hasil berbicara mahasiswa pada akhir siklus I ini mengalami perubahan dibandingkan dengan proses pembelajaran pada prasiklus atau sebelum siklus I. Sebelum siklus I kurang dari setengah mahasiswa yang mencapai KKM (Kriteria Ketuntasan Minimal), hanya 9 orang mahasiswa yang nilainya tuntas. Lima orang nilainya 80 dan empat orang nilainya 70 . Sementara itu, enam belas orang mahasiswa lainnya tidak mencapai Standar Ketuntasan Belajar Minimal.

Perkembangan kemampuan berbicara mahasiswa sebelum siklus I dengan sesudah siklus I terjadi peningkatan yang cukup baik. Nilai berbicara mahasiswa sebelum siklus I rata-rata $65,55 \%$, sedangkan sesudah siklus I atau pada akhir siklus I nilai rataratanya menjadi $85,68 \%$. Hal ini terjadi karena pada proses belajar mengajar, mahasiswa sudah mulai menikmati kegiatan bercerita yang ditugaskan kepada mereka. Selain itu, topik yang dipilih pun sangat disenangi sehingga menggugah semangat dan motivasi mereka untuk berbicara.

Namun demikian, masih terdapat 2 orang mahasiswa yang belum tuntas. Dengan demikian, dapat dikatakan bahwa proses pembelajaran bahasa Indonesia

\section{Peningkatan Keterampilan Berbicara Melalui Teknik Bercerita Mahasiswa Tingkat 1 Program Studi Keperawatan Stikes Syedza Saintika Padang}


terlihat pada akhir siklus I dalam rangka meningkatkan kemampuan berbicara mahasiswa sudah cukup baik namun masih perlu lebih ditingkatkan karena masih terdapat dua orang mahasiswa yang blum tuntas.
Rincian nilai mahasiswa masing-masing indikator yaitu: (1) lafal, (2) kosakata/diksi, (3) Struktur/gramatika (4) isi pembicaraan, (5) pemahaman, (6) kefasihan, dapat dilihat pada tabel berikut ini:

Tabel 1. Kemampuan Berbicara Mahasiswa Secara Umum dengan Teknik Bercerita Siklus I

\begin{tabular}{ccccc}
\hline No & Klasifikasi & Bobot penguasaan & Frekuensi & Persentase \\
\hline 1 & Buruk Sekali & $0-15 \%$ & - & - \\
\hline 2 & Buruk & $16-25 \%$ & - & - \\
\hline 3 & Kurang Sekali & $26-35 \%$ & - & - \\
\hline 4 & Kurang & $36-45 \%$ & - & - \\
\hline 5 & Hampir Cukup & $46-55 \%$ & - & - \\
\hline 6 & Cukup & $56-65 \%$ & 2 & 8 \\
\hline 7 & Lebih dari Cukup & $66-75 \%$ & 2 & 8 \\
\hline 8 & Baik & $76-85 \%$ & 5 & 20 \\
\hline 9 & Baik Sekali & $86-95 \%$ & 10 & 40 \\
\hline 10 & Sempurna & $96-100 \%$ & 6 & 24 \\
\hline & Total & & 25 & 100 \\
\hline
\end{tabular}

Tabel 4.10 tersebut menunjukkan bahwa klasifikasi tertinggi yang dicapai mahasiswa dalam keterampilan berbicara secara umum adalah pada kualifikasi baik sekali. Selain itu, dari penentuan rata-rata diperoleh bahwa kemampuan umum berbicara mahasiswa adalah baik sekali 10 orang dan sempurna 6 orang. Hasil pembelajaran berbicara, diketahui bahwa kemampuan mahasiswa dalam berbicara mengalami perubahan setelah dilakukan PTK. Hal tersebut diketahui bahwa sebelum dilakukan PTK hanya 9 orang mahasiswa yang berhasil mencapai nilai lebih dari 68, namun setelah siklus I maka diketahui bahwa terdapat 23 orang mahasiswa yang memenuhi KKM.

Perkembangan kemampuan berbicara mahasiswa sebelum PTK dilaksanakan dengan setelah siklus I terjadi peningkatan yang baik. Nilai hasil kemampuan berbicara mahasiswa sebelum dilakukan PTK rata-rata 65,55 $\%$, sedangkan sesudah siklus I rataratanya menjadi $85,68 \%$. Hal ini terjadi karena pada proses pembelajaran, mahasiswa diajak untuk berbicara berdasarkan apa yang telah mereka siapkan sebelumnya. Namun pada siklus I ini, masih terdapat 2 orang mahasiswa yang belum mencapai KKM. Dengan demikian proses pembelajaran ini perlu ditingkatkan lagi agar mahasiswa yang belum tuntas bisa mencapai KKM yang ditentukan.

Refleksi adalah kegiatan menganalisis hasil pengamatan peneliti bersama dosen kolaborator untuk menentukan sejauh mana teknik yang digunakan dosen berhasil dalam meningkatkan kemampuan berbicara mahasiswa. Kegiatan refleksi dilakukan

Peningkatan Keterampilan Berbicara Melalui Teknik Bercerita Mahasiswa Tingkat 1 Program Studi Keperawatan Stikes Syedza Saintika Padang 
secara kolaboratif antara peneliti dengan observer/dosen bahasa Indonesia pada setiap akhir pembelajaran.

Berdasarkan hasil pelaksanaan siklus I, penerapan teknik bercerita untuk meningkatkan kemampuan berbicara mendapatkan beberapa masalah dalam pelaksanaannya. Pertama, kelas ribut sehingga mahasiswa yang lain terganggu dalam proses penyajian lisannya, hal ini disebabkan karena pengelolaan kelas yang masih kurang baik, pada pertemuan berikutnya dosen seharusnya lebih menguasai kelas dengan menfokuskan mahasiswa pada proses pembelajaran dan menciptakan suasana pembelajaran yang menarik bagi mahasiswa. Kedua, mahasiswa masih kurang memahami aspek-aspek penilaian keterampilan berbicara hal ini disebabkan karena dosen kurang paham terhadap materi serta penyampaian materi tentang aspek-aspek penilaian kemampuan berbicara disampakan terlalu cepat.

Pada petemuan berikutnya, peneliti disarankan untuk lebih mendalami pemahaman terhadap materi dan lebih pelan dalam menyampaikan materi serta benar-benar memastikan semua mahasiswa memahami materi yang disampaikan. Untuk memastikan semua mahasiswa memahami materi kemampuan penyajian lisan serta aspekaspek penilaian dalam kemampuan berbicara dosen juga dapat menanyakan lebih dulu kepada mahasiswa tentang materi yang telah dijelaskan. Ketiga, mahasiswa mempunyai kelebihan waktu dalam penyajian lisannya. Solusinya dari masalah ini adalah pada pertemuan berikutnya dosen memberikan waktu yang efisien digunakan mahasiswa kirakira 3-5 menit.

Keempat, kurangnya pendekatan dosen kepada mahasiswa yang masih belum memahami materi dalam penyajian lisan, hal ini disebabkan karena dosen kurang memperhatikan mahasiswa yang masih belum paham terhadap materi kuliah. Solusi dari masalah ini adalah pendekatan dosen yang lebih banyak pada mahasiswa yang hasil tes berbicaranya masih rendah pada siklus I.

Namun demikian, masih terdapat 3 orang mahasiswa yang nilainya tetap dengan nilai 70, 80 dan70. Sementara itu, 1 orang mahasiswa nilainya turun, dan 21 orang mahasiswa mengalami kenaikan nilai. Dari 25 orang mahasiswa tersebut 2 orang diantaranya mendapat predikat belum tuntas yaitu dengan nilai 60 . Dengan demikian proses pembelajaran ini perlu ditingkatkan lagi agar mahasiswa yang belum tuntas bisa tuntas dengan nilai yang lebih baik.

Pelaksanaan tindakan siklus II dilaksanakan tanggal 18 Oktober sampai dengan 20 Oktober 2017. Sebagaimana halnya pada siklus pertama, pada siklus kedua ini juga direncanakan dua kali pertemuan. Langkah-langkah yang dilakukan pada siklus kedua ini pada dasarnya sama dengan siklus pertama, yaitu terdiri atas empat tahap yang meliputi perencanaan, pelaksananan tindakan, pengamatan, dan refleksi hasil pengamatan. Adapun langkah-langkah yang akan dilakukan pada siklus II ini adalah sebagai berikut.

\section{Peningkatan Keterampilan Berbicara Melalui Teknik Bercerita Mahasiswa Tingkat 1 Program Studi Keperawatan Stikes Syedza Saintika Padang}




\section{Tabel 2. Hasil Tes Kemampuan Berbicara Mahasiswa Tingkat 1 STIKes Syedza} Saintika

\begin{tabular}{cccccc}
\hline \multicolumn{2}{c}{ Sebelum PTK } & \multicolumn{2}{c}{ Siklus I } & \multicolumn{2}{c}{ Siklus II } \\
\hline \multicolumn{2}{c}{ Tuntas } & \multicolumn{2}{c}{ Tuntas } & \multicolumn{2}{c}{ Tuntas } \\
\hline Ya & Tidak & Ya & Tidak & Ya & Tidak \\
\hline 9 & 16 & 23 & 2 & 25 & - \\
\hline
\end{tabular}

Dari tabel di atas dapat lihat bahwa terjadi peningkatan kemampuan berbicara mahasiswa menggunakan teknik bercerita. Sebelum dilaksanakannya penelitian tindakan kelas lebih dari setengah jumlah mahasiswa tidak tuntas dan hanya 9 orang mahasiswa saja yang tuntas. Pada siklus pertama terjadi peningkatan yang drastis yaitu 23 orang mahasiswa yang tuntas dan hanya 2 orang mahasiswa yang belum berhasil dalam mencapai nilai batas KKM yaitu 68. Sedangkan pada siklus kedua semua mahasiswa mencapai nilai di atas KKM.
Dari hasil yang diperoleh, dapat diketahui bahwa terjadi peningkatan nilai rata-rata. Pada kemampuan awal nilai rata-rata mahasiswa adalah $65,55 \%$, siklus I meningkat menjadi 85,68 \%, sedangkan pada siklus II menjadi 88,96 $\%$. Oleh karena itu, pembelajaran berbicara dengan teknik bercerita dalam penelitian tindakan kelas ini tidak dilanjutkan ke siklus selanjutnya karena semua mahasiswa sudah mencapai nilai KKM yaitu $\asymp 68 \%$.

Tabel 3. Hasil Penilaian Keterampilan Berbicara Mahasiswa

\begin{tabular}{ccccc}
\hline No & Kualifikasi & Sebelum PTK & Siklus I & Siklus II \\
\hline 1 & Buruk Sekali & - & - & - \\
\hline 2 & Buruk & - & - & - \\
\hline 3 & Kurang Sekali & - & - & - \\
\hline 4 & Kurang & 2 & - & - \\
\hline 5 & Hampir Cukup & 7 & - & - \\
\hline 6 & Cukup & 7 & 2 & - \\
\hline 7 & Lebih dari Cukup & 4 & 2 & 1 \\
\hline 8 & Baik & 5 & 5 & 5 \\
\hline 9 & Baik Sekali & - & 10 & 5 \\
\hline 10 & Sempurna & - & 6 & 14 \\
\hline
\end{tabular}

Pada tabel di atas terlihat bahwa perkembangan nilai mahasiswa dari sebelum perlakuan penelitian tindakan kelas dengan setelah dilakukan penelitian tindakan kelas cukup baik, bahkan setelah siklus II keterampilan berbicara mahasiswa bertambah baik. Hal ini terlihat pada siklus I, sepuluh orang mahasiswa memperolrh predikat baik sekali, sementara pada siklus II 
meningkat lagi menjadi empat belas orang mahasiswa mendapatkan predikat baik sekali. Dengan demikian, penggunaan teknik bercerita dalam rangka meningkatkan kemampuan berbicara mahasiswa dalam proses pembelajaran bahasa Indonesia cukup membantu dan memberikan perubahan terhadap hasil belajar mahasiswa.

\section{SIMPULAN}

Dari uraian sebelumnya, dapat diambil kesimpulan bahwa penggunaan teknik bercerita berpengaruh sangat besar terhadap peningkatan keterampilan berbicara. Hal ini terlihat dalam hasil pengamatan pada siklus I dan siklus II. Pengguanaan teknik bercerita dalam pembelajaran keterampilan berbicara dirancang dalam bentuk Rencana pelaksanaan Semester (RPS). RPS tersebut disusun dengan berpedoman kepada Silabus yang dirancang oleh tim dosen mata kuliah Bahasa Indonesia di Sekolah Tinggi Ilmu Kesehatan Seyedza Saintika Padang. Hasil evaluasi yang dihasilkan yaitu terlihat dari keterampilan berbicara mahasiswa pada siklus I dengan nilai rata-rata $65,55 \%$ dengan klasifikasi lebih dari cukup, sedangkan pada siklus II dihasilkan nilai keterampilan berbicara dengan rata-rata mahasiswa 88,96\% dengan klasifikasi baik sekali. Berdasarkan perbandingan keberhasilan keterampilan berbicara mahasiswa pada tahap prasiklus dan siklus I, dapat diketahui bahwa nilai ratarata kemampuan mahasiswa mengalami kenaikan 20,13\%, selanjutnya siklus I dan siklus II mengalami kenaikan 3,28\%. Hasil tes tersebut menunjukkan adanya peningkatan dalam pembelajaran keterampilan berbicara dengan menggunakan teknik bercerita.
Selain

itu,

peningkatan

keterampilan berbicara mahasiswa juga didukung oleh beberapa faktor diantaranya: 1) mahasiswa lebih sering diberikan latihan-latihan berbicara dengan menggunakan berbagai teknik pembelajaran, 2) materi atau konsep yang diterima mahasiswa benar-benar baik misalnya pemberian contoh yang tidak jauh dari kehidupan mahasiswa sehingga dapat dimengerti dan dipahami oleh mahasiswa. Jadi pembelajaran keterampilan berbicara dengan menggunakan teknik bercerita mahasiswa tingkat 1 program studi keperawatan STIKes Syedza Saintika Padang dapat meningkat.

\section{E. REKOMENDASI}

Berdasarkan simpulan penelitian, maka dapat dikemukakan beberapa saran yang dapat dipertimbangkan sebagai salah satu alternatif model pembelajaran berbicara di STIKes yaitu: 1) disarankan kepada dosen mata kuliah bahasa Indonesia yang juga melakukan pembelajaran keterampilan berbicara agar dapat mempergunakan teknik bercerita, 2) disarankan kepada dosen mata kuliah bahasa Indonesia agar lebih kreatif mempergunakan teknik pembelajaran keterampilan berbicara seperti menggunakan teknik bercerita dengan penyajian lisan agar mahasiswa lebih tertarik untuk mengikuti pembelajaran bahasa Indonesia.

\section{Peningkatan Keterampilan Berbicara Melalui Teknik Bercerita Mahasiswa Tingkat 1 Program Studi Keperawatan Stikes Syedza Saintika Padang}




\section{DAFTAR PUSTAKA}

Abdurahman dan Elya Ratna. (2003) .Evaluasi Pembelajaran Bahasa Indonesia (Buku Ajar). Padang: FBSS UNP.

Akhadiah, Sabarti. (1988). Evaluasi dalam Pengajaran Bahasa. Jakarta: Depdikbud Dirjen Pendidikan Tinggi Jakarta.

Arief, Ermawati dan Yarni Munaf. (2003). Pengajaran Keterampilan Berbicara (Buku Ajar). Padang: Jurusan Bahasa dan Sastra Indonesia FBSS UNP.

Arikunto, Suharsimi. (2006). Penelitian Tindakan Kelas. Jakarta: Bumi Aksara.

Arsjad, Maidar G. dkk. (1991). Pembinaan Kemampuan Berbicara Bahasa Indonesia. Jakarta: Erlangga.

Depertemen Pendidikan Nasional. (2002). Kamus Besar Bahasa Indonesia. Jakarta: Balai Pustaka.

Hendrikus, Dori Wuwur. (1991). Retorika. Yogyakarta: Kanisius.

Hidayat, Kosadi dkk. (1987). Strategi Belajar Mengajar Bahasa Indonesia. Bandung: Binacipta.

Hidayati, Nia. (2009). Manfaat Cerita Bagi Kepribadian Anak. http://niahidayati.net/manfaat- cerita-bagi-kepribadian-

anak.html\#more696.

Keraf, Gorys. (1996). Terampil Berbahasa Indonesia. Jakarta: Balai Pustaka.

Nursaid. (2006). Kurikulum 2006 Bahasa Indonesia. Padang: Jurusan Bahasa dan Sastra Indonesia FBSS UNP.

Osborne, Jhon W. (1990). Kiat Berbicara di Depan Umum untuk Eksekutif. a. b. Walfred Andre. Jakarta: Bumi Aksara.

Saliwangi, Basennang. (1989). Pengantar strategi Belajar Mengajar Bahasa Indonesia. Malang: IKIP Malang.

Sameto, Hudoro. (2004). Cara Berbicara dan Presentasi dengan AudioVisual. Jakarta: Gramedia Pustaka Utama.

Suhendar dan Pien Supinah. (1997). Pengajaran dan Ujian Keterampilan Menyimak dan Keterampilan Berbicara. Bandung: Pionir Jaya.

Tarigan dan Hendry Guntur Tarigan. (1990). Teknik Pengajaran Keterampilan Berbahasa. Bandung: Angkasa.

Tarigan, Henry Guntur. (1985). Berbicara sebagai Keterampilan Berbahasa. Bandung: Angkasa. 